\title{
A study on the financial awareness among women entrepreneurs in Kottayam district
}

\author{
Reshma Rachel Kuruvilla, ${ }^{1, *}$, P N Harikumar² \\ ${ }^{1}$ Research Scholar, ${ }^{2}$ Research Guide, Dept. of Commerce, Bharathiar University, Coimbatore, Tamil Nadu, India
}

*Corresponding Author:

Email: rrk1711@gmail.com

\begin{abstract}
Women were ignored always in money making and financial management. They were not even given proper education. Even educated people are found to be illiterate in financial matters. The term financial literacy has huge importance for a business house since the impact of an uniformed decision making for a business house cannot be predicted in advance. Relationship between educational status of the entrepreneur and the marks scored in the test to measure financial knowledge was done using correlation coefficient. Author also made an attempt to know about the gaps in the financial literacy among women entrepreneurs to identify areas which need attention.
\end{abstract}

Keywords: Financial, Management.

\section{Introduction}

Capital is a major requirement for the growth of all enterprises. It is the entrepreneurs who mobilize resources of the country for their own growth which will indirectly facilitate the growth of the country. So actions of the entrepreneurs are deciding factors for the economic development of the country. Therefore, lot of support has been extended by Government for the upliftment of entrepreneurship in the country. Despite all the efforts, availability of finance and financial services remain an obstacle for many enterprises. Though the RBI report published in the year 2005 recognize the concerns about financial inclusion, many vulnerable groups are still out of the reach of the banks. In India, social condition of women is low and their economic conditions remains much below than that of men. Financial services provided to them is also low. The condition of women managed enterprises has to be improved.

According to the Government of India, for an enterprise to be classified as a women managed enterprise, It should be controlled and owned by women holding atleast $51 \%$ of the capital of the enterprise and atleast 51\% employed personnels should be women. Zulfiqar. M. (2015) tried to conduct a study on women's economic empowerment through financial attitude, financial literacy, and financial wellbeing. His study was done to assess the level of financial literacy, financial wellbeing and financial attitude of working women and to examine the relationship between economic empowerment of working women and the variables like financial literacy, financial attitude, financial wellbeing. Study is conducted on 300 working women of nonfinancial sector of Pakistan. Zulficar found that the variables are significantly \& positively related with economic empowerment of women.

If conditions of women managed enterprises has to be improved, condition of women also has to be improved.
Therefore, main aim of the research was to study about the financial awareness among women entrepreneurs (i.e. women running their own businesses).

\section{Statement of the problem}

Across the globe, women were neglected and are denied even the fundamental rights like education. We are living in a social system in which males hold primary power and authority. In majority of the homes, men are getting special privilege and control of the property and hence most of the women entrepreneurs have difficulty in accessing the credit due to the need for collaterals.

India is a country where the percentage of female population is less than the proportion of the male population. According to the child sex ratio published by UNICEF, birth rate of females is declining steadily. Child sex ratio in India was 947 girls for 1,000 boys in the year 1991. Almost all the districts of India showed signs of declining sex ratio. But Kerala was an exception. Gujarat, Maharashtra, Punjab, Himachal Pradesh and Haryana shows a decline in the child sex ratio more than 50 point. But today, the numbers have started to improve showing signs of progress for the country. Increase in number of women alone cannot be said as progress, but the number of women who are capable to generate income should increase for a country to transform itself as a developed one. But globally, though women constitute two third of the burden of the world's work, only one tenth of the income is received by them. This happens because of a patriarchal society where Men predominate over women in every sphere of life, particularly in the economic life. Usually decision making on resources, and utilization of her earnings are handled by their male counterparts since majority of the women are not aware about financial matters and about financial products and services. 
But women need to be sufficiently financially literate to take effective financial decisions for the proper utilization of household resources and for proper economic involvement for better lives for the present generations as well as for the future generations. Women are the ones responsible for transmitting financial habits to the future generations too. Hence, financial literacy among women is very important. Financial literacy is not a requirement which is needed to improve women's management of their personal and household finances alone, but it aims to empower women to equip them to be able to select and have proper access to appropriate financial services and products, as well as to develop and manage their economic activities.

\section{Significance of the Study}

Majority of the women are suffering a lot due to a patriarchal society. Low women literacy rate is a major pullback for the development of women and the society at large. Development of women is important for the society since women are the ones responsible for child rearing and development of the future generations. If businesses managed by women develop, then that will lead to the progress of the society at large. Financial literacy is very important for the proper conduct and management of the business. Hence the study is significant.

\section{Literature Review}

According to a research published from George Washington University, around the globe women lag behind men in their levels of financial literacy. Challenge is to overcome from this gender gap by solving all issues connected with finance.

Financial education is about learning of matters connected with finances and the financial environment through a course of study. Scope of financial education has grown wide. Financial education is all about financial literacy, financial expectations, and satisfaction in matters connected with finance. (Hira \& Loibl, 2005).

Emira Kozarevic et al. (2016) is of the opinion that financial knowledge of the management plays an important role in their ability to take important financial decisions. The lack of financial knowledge is poised as a cause for the global financial crisis. Large variety of financial products and services are available today for both individuals and the establishments making it complex to take informed financial decisions. Quality of decisions taken by businesses will depend on a large extent on the knowledge level of the decision makers. It has been pointed out by the authors that financial literacy could be one of the key factors promoting economic growth, as decisions taken by management knowingly or unknowingly will directly affect the profitability of the businesses, and, ultimately the overall economy of the society to which the business houses belongs.

Ms Gurveen Kaur et al (2017) is of the opinion that many women, from both urban and rural India could not realize their entrepreneurial dreams because of the unavailability of sufficient banking facilities due to limited financial inclusion. Author is of the view that meeting the objective of financial inclusion among women entrepreneurs can improve the socio-economic development of the country too. But developing financial services in accordance with the changing needs of the women entrepreneurs and educating them about the newly designed products and services is an important factor for the growth of the financial inclusion programmes.

Musa Abdullahi Bayero (2015) through his paper made an attempts to study about the linkage between women entrepreneurship and financial inclusion. Conceptual papers, previous reports and empirical papers were reviewed in order to establish a connecting link between financial inclusion and women entrepreneurship. Author concludes by saying that women can be counted to be responsible for a large share of adult percentage who are out of the financial inclusion criteria despite their potential for being a major contributor for economic development. It is very important to know the factors prohibiting women in getting access to formal financial services. Understanding the fundamental issues surrounding women access to formal financial services is necessary for any meaningful progress to be achieved. Therefore, in order to promote financial inclusion of women regulatory focus should be directed towards innovations and improvements in financial products and delivery models, and strengthening financial consumer protection. Similarly, financial institutions need to adopt gender sensitive policies and practices in the areas of product design, monitoring, marketing, and delivery. Finally, there is need to identify and address women's need for financial literacy

(OECD, 2012; World Bank, 2013) draws attention to the point that in order to achieve success in entrepreneurship, proper access to finance should be provided to male as well as women entrepreneurs. Awareness about the innovative financial products designed for women entrepreneurs should be communicated through the various training sessions organized to ensure that women have proper access to financial products. For availing the benefit of appropriate financial product, financial literacy is a pre requisite.

\section{Objectives of the Study}

1. To identify if there is a relationship between educational status and the level of financial literacy among women entrepreneurs.

2. To identify the financial literacy gap among the women entrepreneurs. 
Hypotheses of the study are: H0: There is no association between financial knowledge scores and the educational status of the entrepreneurs.

\section{Research Methodology}

Primary and secondary data were used during the analysis. Primary data were collected through interview schedule. 50 sample respondents are used for the study based on simple random sampling. Statistical tools gap analysis and percentages were used to find out the desired result. Pearson coefficient was used to find out the association between the variables under study. Educational status of the entrepreneurs and their level of financial knowledge were the variables used in the study. Financial knowledge of the respondents were determined on the basis of a test and scores of the test were categorized into 3 levels.

\section{GAP Analysis of the Financial Literacy}

Literacy reflects the socio economic conditions and well being of the citizens of a nation. Gender gap in literacy is a constraint for the development of an individual as well as for the nation to which the individual belongs. It is very well known that it is impossible to succeed today in the modern world without the basic literacy skills. Since, financial literacy is not literacy in itself. It is the ability to read and write and to have informed decision making skills for better planning for the future of a person. Thus, in future, it will be impossible to succeed in the present-day business system without having the basic knowledge of finance and economics.

Consumers who fail to understand the basic concepts of financial knowledge might depend more on loans and debts, and incur higher interest rates on loans", their borrowals might go up more than their earnings and savings. An attempt was made to understand the deviations in the literacy gap among the women entrepreneurs to know their level of financial literacy.

Table 1: GAP analysis

\begin{tabular}{|l|l|c|c|c|c|}
\hline S. No. & Dimensions & $\begin{array}{c}\text { Exp Mean } \\
\text { Score }\end{array}$ & $\begin{array}{c}\text { Experienced } \\
\text { Mean Score }\end{array}$ & $\begin{array}{c}\text { Literacy } \\
\text { Gap }\end{array}$ & $\begin{array}{c}\text { Std } \\
\text { Deviation }\end{array}$ \\
\hline 1. & $\begin{array}{l}\text { Familiarity with the dates of } \\
\text { depositing and } \\
\text { withdrawing of money in bank } \\
\text { account }\end{array}$ & 5 & 3.8 & 1.2 & 1.10 \\
\hline 2. & $\begin{array}{l}\text { Knowledge about the time value of } \\
\text { money }\end{array}$ & 5 & 1.08 & 3.92 & 1.10 \\
\hline 3. & $\begin{array}{l}\text { Knowledge about preparation of } \\
\text { various types of budgets. }\end{array}$ & 5 & 2.04 & 2.96 & 1.25 \\
\hline 4. & $\begin{array}{l}\text { Knowledge about various sources } \\
\text { for accessing credit. }\end{array}$ & 5 & 2.30 & 2.7 & 1.15 \\
\hline 5. & $\begin{array}{l}\text { Knowledge about various sources } \\
\text { for investing the surplus funds. }\end{array}$ & 5 & 3.3 & 1.7 & 1.20 \\
\hline
\end{tabular}

A financial literacy gap greater than 2.5 was considered to be an area which requires at most attention. Literacy gap in between 1.5 and 2.5 was important, but is of lesser importance compared to the gap greater than 2.5. Literacy gap less than 1.5 is to be addressed with superiority. Knowledge about the time value of money is very less among the entrepreneurs and should be dealt with seriously.

Table 2: Educational status of the entrepreneur

\begin{tabular}{|l|l|c|c|c|c|}
\hline \multicolumn{2}{|c|}{} & Frequency & Percent & Valid Percent & Cumulative Percent \\
\hline Valid & Illiterate & 5 & 10.0 & 10.0 & 10.0 \\
\cline { 2 - 6 } & Primary education & 5 & 10.0 & 10.0 & 20.0 \\
\cline { 2 - 6 } & Graduation & 28 & 56.0 & 56.0 & 76.0 \\
\cline { 2 - 6 } & Post graduation & 6 & 12.0 & 12.0 & 88.0 \\
\cline { 2 - 6 } & Professional & 6 & 12.0 & 12.0 & 100.0 \\
\cline { 2 - 6 } & Total & 50 & 100.0 & 100.0 & \\
\hline
\end{tabular}

Out of the 50 women entrepreneurs surveyed, $10 \%$ were illiterates, $10 \%$ had primary education only, $56 \%$ were graduates, $12 \%$ post graduates and $12 \%$ were professionals. This was done to know about the educational status of the respondents. 
Table 3: Marks secured based on financial knowledge

\begin{tabular}{|c|c|c|c|c|c|}
\hline & Frequency & Percent & Valid Percent & Cumulative Percent \\
\hline \multirow[t]{4}{*}{ Valid } & less than 50 marks & 3 & 6.0 & 6.0 & 6.0 \\
\hline & between 50 and 60 marks & 31 & 62.0 & 62.0 & 68.0 \\
\hline & Above 60 marks & 16 & 32.0 & 32.0 & 100.0 \\
\hline & Total & 50 & 100.0 & 100.0 & \\
\hline
\end{tabular}

Majority of the respondents got a score above 60 marks for a test conducted to know their knowledge on financial matters. Only 6 percent scored less than 50 marks which is a sign that majority of the women entrepreneurs have the required basic awareness about financial matters.

Another aspect analysed was whether the educational status of the entrepreneur is a determining factor in the financial literacy level of the women entrepreneur.

Pearson coefficient of correlation was used to know the correlation between the educational status of the entrepreneur and their marks scored based on their financial knowledge.

Table 4: Correlations

\begin{tabular}{|c|c|c|c|}
\hline & & Marks scored & $\begin{array}{c}\text { Educational Status of } \\
\text { the entrepreneur }\end{array}$ \\
\hline \multirow[t]{3}{*}{ Marks scored } & Pearson Correlation & 1 & $.452^{* *}$ \\
\hline & Sig. (2-tailed) & & .001 \\
\hline & $\mathrm{N}$ & 50 & 50 \\
\hline \multirow{3}{*}{$\begin{array}{l}\text { Educational Status of the } \\
\text { enterpreneur }\end{array}$} & Pearson Correlation & $.452^{* *}$ & 1 \\
\hline & Sig. (2-tailed) & .001 & \\
\hline & $\mathrm{N}$ & 50 & 50 \\
\hline
\end{tabular}

From the test result, it can be seen that $\mathrm{p}$ value is less than 0.05 , we will reject the null hypothesis. Here null nypothesis states that there is no correlation between the variables under study. Hence, here we can conclude that there is a relationship between variables.

\section{Findings of the Study}

1. From the findings, it can be understood that educational status of the entrepreneur is related with the marks scored by the entrepreneurs in the test conducted to measure financial knowledge.

2. Majority of the women entrepreneurs had sufficient literacy of the basic financial matters. But their knowledge is limited only to the basic matters.

\section{Conclusion}

Financial literacy is a term which is highly important from the viewpoint of business. Informed decision making can lead to the profitability of the businesses. Entrepreneurs should be given proper training to improve their financial knowledge on time value of money and budget preparation. It is also important to keep them informed about various sources for availing credit at cheaper rates.

\section{References}

1. Kothri, C.R \& Garg Gaurav., Research Methodology, New Age International Pvt. Ltd., New Delhi, 2014

2. Kumar D. Empowerment of Women. Kisan World. 2006;33(10):21-23.
3. Government of India (2008), Committee on Financial Inclusion. (Chairman: Dr. C. Rangarajan).

4. RBI (2005). Report on Rural Credit and micro finance. (Chairman: H.R. Khan).

5. RBI (2014a). Report on comprehensive financial services for small businesses and low Income households. (Chairman: Dr. N. Mor).

6. https://www.researchgate.net/publication/301292818_EX PLORING_THE_LINK_BETWEEN_FINANCIAL_INC LUSION_AND_WOMEN_ENTREPRENEURSHIP [accessed Aug 15 2018].

7. Lusardi, A. and Mitchell, O. S. Financial literacy and retirement preparedness, Evidence and implications for financial education. Business Economics. 2007;42:35-44.

8. Agarwala, S.K., Barua, S., Jacob, J. and Verma, J. R. (2013), Financial literacy among working young in urban India, Working Paper, IIM-Ahmedabad.

9. Hira, T., and Loibl, C. (2007), A typology of investors: Identification of teachable moments and key investment topics. Investor Report. Sponsored by NASD Investor Education Foundation.

10. Hira, T. K., Fanslow, A. M., \& Vogelsang, R. Determinants of satisfaction with preparation for financial emergencies. Financial Counseling and Planning Education. 1992;3:43-62.

11. Agier. I \& Szafarz, A. Microfinance and gender is there a glass ceiling on loan Size? World development. 2013;42:165-181.

12. OECD INFE (2011), Measuring Financial Literacy: Core Questionnaire in Measuring Financial Literacy: Questionnaire and Guidance Notes for conducting an Internationally Comparable Survey of Financial Literacy. Paris: OECD.

13. Kahneman, D., and A. Tversky. Prospect theory: an analysis of decision under risk. Econometrica. 1979;47(2):263-291. 
14. Volpe, Ronald P., Joseph E. Kotel, and Haiyang Chen. A Survey of Investment Literacy Among Online Investors. Financial Counseling and Planning. 2002;13:1-13.

15. Huston, Sandra. J. Measuring Financial Literacy. The Journal of Consumer Affairs. 2010;44:296-316.

16. Nair Lekshmi, "Financial Sector Liberalization and Household Savings in India., M.Phil Thesis submitted to the Jawaharlal Nehru University.

17. Prudential research. (2010-11) Financial experience and behaviours among women. Prudential. 